\title{
Properties and Uses of Chlorpyrifos in the United States
}

\author{
Keith R. Solomon, W. Martin Williams, Donald Mackay, \\ John Purdy, Jeffrey M. Giddings, and John P. Giesy
}

\section{Introduction}

The physical and chemical properties of chlorpyrifos $(O, O$-diethyl $O-3,5$, 6-trichloro-2-pyridinyl phosphorothioate, CPY; CAS No. 2921-88-2) are the primary determinants that govern fate (movement, adsorption, degradation, and catabolism) in the environment and in biota. The uses of chlorpyrifos in locations of interest, such as the United States in the case of this paper, are the primary determinants of the entry of chlorpyrifos into the environment and its subsequent fate in the regions of use and beyond. The uses and manner of use are addressed in this paper.

The data on physical and chemical properties provided here were the basis for modeling long range transport and assessing bioaccumulation (Mackay et al. 2014), characterizing routes of exposure to chlorpyrifos in terrestrial systems such as soil,

The online version of this chapter (doi:10.1007/978-3-319-03865-0_2) contains supplementary material, which is available to authorized users.

K.R. Solomon $(\square)$

Centre for Toxicology, School of Environmental Sciences, University of Guelph,

Guelph, ON, Canada

e-mail: ksolomon@uoguelph.ca

W.M. Williams

Waterborne Environmental Inc., Leesburg, VA, USA

D. Mackay

Trent University, Peterborough, ON, Canada

J. Purdy

Abacus Consulting, Campbellville, ON, Canada

J.M. Giddings

Compliance Services International, Rochester, MA, USA

J.P. Giesy

Department of Veterinary Biomedical Sciences and Toxicology Centre,

University of Saskatchewan, 44 Campus Dr., Saskatoon, SK S7N 5B3, Canada 
foliage, and food items (Cutler et al. 2014; Moore et al. 2014), and in surface-water aquatic systems (Giddings et al. 2014; Williams et al. 2014). The currently-registered formulations of chlorpyrifos and their uses in the United States were the basis for the development of the scenarios of exposure and the conceptual models used in assessing risks to birds (Moore et al. 2014), pollinators (Cutler et al. 2014), and aquatic organisms (Williams et al. 2014). These data on use are based on the current labels and reflect changes in labels and use-patterns since the earlier assessments of risks to aquatic (Giesy et al. 1999) and terrestrial organisms (Solomon et al. 2001). Physical and chemical properties of chlorpyrifos were extensively reviewed by Racke (1993) and, rather than repeat all of this information, relevant values from Racke 1993 are included in this paper and supplemental material (SI) with updates as appropriate.

\section{Physical and Chemical Properties of Chlorpyrifos}

Fundamental to assessing and predicting the general fate of chlorpyrifos in the environment are having reliable data on physical chemical and reactivity properties that determine partitioning and persistence in the environment. In the following sections, some of the key properties are discussed in more detail.

\subsection{Properties Affecting Fate in Air and Long-Range Transport}

The fate of CPY and chlorpyrifos-oxon (CPYO; CAS No. 5598-15-2; CPY's biologically active metabolite, degradate, and minor technical product component) in air, with respect to short- and long-distance transport are discussed in detail in a companion paper (Mackay et al. 2014). The physical and chemical properties specific to fate in air are presented in Tables 5-8 in Mackay et al. (2014) and are not repeated here except in the context of biological relevance and fate and movement in other matrices.

\subsection{Properties Affecting Fate in Soil, Water, and Sediment}

An extensive review of the data on half-lives of CPY in soils and has shown the high variability attributed to soil organic carbon content, moisture, application rate and microbial activity (Racke 1993). Fewer data are available for water and sediments, but processes related to soils and sediments have been summarized in a recent review (Gebremariam et al. 2012). The key physical and chemical properties of CPY are listed in Tables 1 and 2.

Chlorpyrifos has short to moderate persistence in the environment as a result of several dissipation pathways that might occur concurrently (Fig. 1). Primary mechanisms of dissipation include volatilization, photolysis, abiotic hydrolysis, and 
Table 1 Physicochemical properties of chlorpyrifos

\begin{tabular}{|c|c|c|}
\hline Parameter & Values for Chlorpyrifos & Source \\
\hline Chemical Name & $\begin{array}{l}\text { O,O-diethyl o-(3,5,6-trichloro-2-pyridyl } \\
\text { phosphorothioate }\end{array}$ & USEPA (2011b) \\
\hline $\begin{array}{l}\text { Chemical Abstracts Service } \\
\text { (CAS) Registry Number }\end{array}$ & $2921-88-2$ & \\
\hline Empirical formula & $\mathrm{C}_{9} \mathrm{H}_{11} \mathrm{Cl}_{3} \mathrm{NO}_{3} \mathrm{PS}$ & \\
\hline USEPA Pesticide Code (PC \#) & 59101 & \\
\hline Smiles notation & $\begin{aligned} \mathrm{S}= & \mathrm{P}(\mathrm{OC} 1=\mathrm{NC}(=\mathrm{C}(\mathrm{C}=\mathrm{C} 1 \mathrm{Cl}) \mathrm{Cl}) \mathrm{Cl})(\mathrm{OCC}) \\
& \mathrm{OCC}\end{aligned}$ & \\
\hline Molecular mass & $350.6 \mathrm{~g} \mathrm{~mol}^{-1}$ & Mackay et al. \\
\hline Vapor pressure $\left(25^{\circ} \mathrm{C}\right)$ & $1.73 \times 10^{-5}$ torr & (2014) \\
\hline Water solubility $\left(20^{\circ} \mathrm{C}\right)$ & $0.73 \mathrm{mg} \mathrm{L}^{-1}$ & \\
\hline Henry's Law Constant & $1.10 \times 10^{-5} \mathrm{~atm} \mathrm{~m}^{-3} \mathrm{~mol}^{-1}$ & \\
\hline $\log \mathrm{K}_{\mathrm{OW}}$ & 5.0 & \\
\hline
\end{tabular}

Table 2 Environmental fate properties of chlorpyrifos

\begin{tabular}{|c|c|c|}
\hline Parameter & Values & Source \\
\hline \multirow[t]{3}{*}{ Hydrolysis ( $\left.\mathrm{t}^{1} / 2\right)$} & $\mathrm{pH} \mathrm{5:73d}$ & \multirow[t]{3}{*}{ USEPA (2011b) } \\
\hline & $\mathrm{pH} 7: 72 \mathrm{~d}$ & \\
\hline & $\mathrm{pH} 9: 16 \mathrm{~d}$ & \\
\hline Aqueous photolysis $\left(\mathrm{t}^{1} / 2\right)$ & $29.6 \mathrm{~d}$ & \\
\hline Aerobic soil metabolism ( $\left.\mathrm{t}^{1} / 2\right)$ & $\begin{array}{l}2-1,576 \mathrm{~d}, \mathrm{~N}=68 \text { (next highest value } \\
\text { is } 335 \mathrm{~d} \text { ) }\end{array}$ & See SI Table A-1 \\
\hline Aerobic aquatic metabolism ( $(\mathrm{t} / 2)$ & $22-51 \mathrm{~d}, \mathrm{~N}=3$ & See SI Table A-5 \\
\hline Anaerobic soil metabolism ( $\left(\mathrm{t}^{1 / 2}\right)$ & 15 and $58 \mathrm{~d}$ & USEPA (2011b) \\
\hline Anaerobic aquatic metabolism ( $\left.\mathrm{t}^{1} / 2\right)$ & 39 and $51 \mathrm{~d}$ & \\
\hline Soil adsorption coefficient $\mathrm{K}_{\mathrm{OC}}$ & $973-31,000 \mathrm{~mL} \mathrm{~g}^{-1}, \mathrm{~N}=33$ & See SI Table A-4 \\
\hline Terrestrial field dissipation $\left(t^{1} / 2\right)$ & $2-120 \mathrm{~d}, \mathrm{~N}=58$ & See SI Table A-3 \\
\hline
\end{tabular}

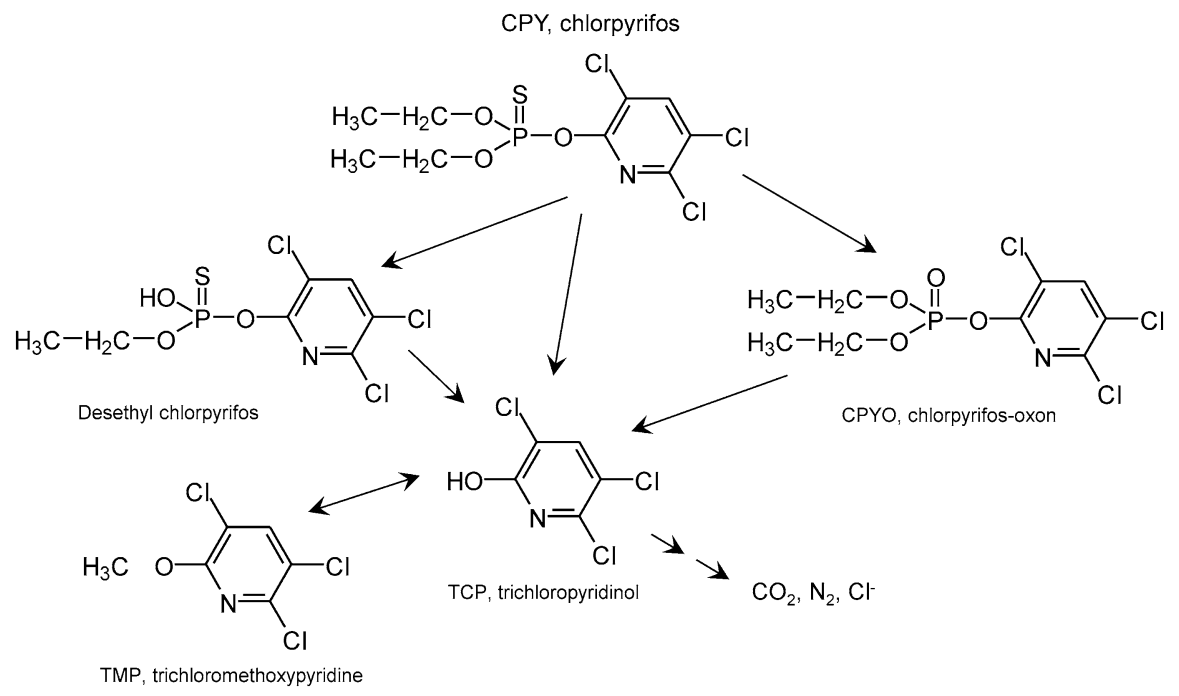

Fig. 1 Pathways for degradation of chlropyrifos in the environment (after Racke 1993) 
microbial degradation. Volatilization dominates dissipation from foliage in the initial $12 \mathrm{~h}$ after application, but decreases as the formulation adsorbs to foliage or soil (Mackay et al. 2014). In the days after application, CPY adsorbs more strongly to soil, and penetrates more deeply into the soil matrix, and becomes less available for volatilization; other degradation processes become important.

Dissipation from soil. Factors affecting degradation of CPY in soil have been reviewed by Racke (1993). The key values that affect soil dissipation have been updated and are presented in SI Table A-1. Photolysis and oxidation are known to form CPYO in air (Mackay et al. 2014) and on foliar surfaces. These routes are either insignificant in soil or CPYO degrades as quickly as it is formed, since CPYO has only been formed in undetectable or small amounts in studies that have used radiotracers to investigate degradation in soils in the laboratory (de Vette and Schoonmade 2001; Racke et al. 1988) or field (Chapman and Harris 1980; Rouchaud et al. 1989). The primary degradation pathway in soil involves hydrolysis to yield 3,5,6-trichloropyridinol (TCP, Fig. 1) from either CPY or CPYO. Results of several studies have shown that this step can be either abiotic or biotic, and the rate is 1.7- to 2 -fold faster in biologically active soils. Both modes of hydrolysis can occur in aerobic and anaerobic soil. The rate of abiotic hydrolysis is faster at higher $\mathrm{pH}$. Hydrolysis is also faster in the presence of catalysts such as certain types of clay (Racke 1993). Degradation of the intermediate, TCP, is dependent on biological activity in soil, and leads to formation of bound residues and reversible formation of 3,5,6-trichloro-2-methoxypyridinol (TMP; Fig. 1). Under aerobic conditions, the primary, terminal degradation product of CPY is $\mathrm{CO}_{2}$. Since TCP and TMP are not considered to be residues of concern (USEPA 2011b), they were not included in characterizations of exposures presented here or the assessment of risk in the companion papers. Because of rapid degradation in soil (see above), CPYO (Fig. 1) was not included in the characterization of exposures via soil.

The half-life for degradation of CPY in soils, based on results of studies conducted under standardized laboratory conditions, ranged from 2 to $1,575 \mathrm{~d}(\mathrm{n}=68$, next highest value is $335 \mathrm{~d}$; SI Table A-1). This range in rates of degradation was attributed to differences in soil organic carbon content, moisture, rate of application, and microbial activity in the reported studies (Racke 1993); however, quantitative relationships between these potential drivers and rates of degradation have not been developed. Greater rates of application resulted in slower degradation, possibly due to the concentration in soil-water reaching the solubility limit of approximately $1 \mathrm{mg} \mathrm{L}^{-1}$, which affects bioavailability to microbiota. The formulation applied can affect results; dissipation from material applied as the granular product is slower (Racke 1993). Half-lives for dissipation from soils determined under field conditions have been reported to range from 2 to $120 \mathrm{~d}(\mathrm{~N}=58$; SI Table A-2).

Biphasic dissipation. Results of studies of aerobic degradation of CPY in soils under laboratory conditions exhibit bi-phasic behavior in most soils. Initial rates of degradation are greater than overall degradation rates by factors of 1.1 to 2.9 (Racke 1993). This behavior of CPY is also variable and not as apparent for some of the soils studied, for which half-lives were calculated by using simple first-order 
Fig. 2 Schematic diagram of a two-compartment kinetic model for chlorpyrifos (CPY) degradation

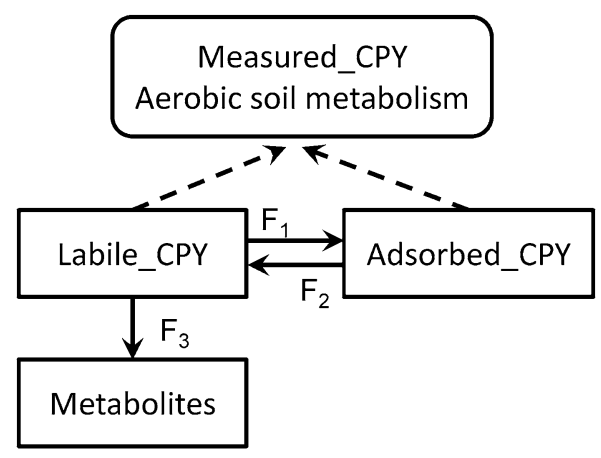

kinetics (de Vette and Schoonmade 2001). Nonetheless, some of the half-lives reported in SI Table A-2 that have been derived from 1st-order degradation kinetics might overestimate the persistence of CPY in the environment.

There have been several approaches to calculate rate constants of degradation for this biphasic degradation of CPY. The DT $_{50}$ values reported by Bidlack were calculated using the Hamaker two-compartment kinetic model (Nash 1988), but details of the goodness of fit were not provided and the $\mathrm{DT}_{50}$ values do not correspond to degradation rate constants (Bidlack 1979). Also, bi-phasic degradation, described by use of the double first-order parallel (DFOP) model, best characterized the data from three dissipation studies performed in terrestrial environments (Yon 2011).

To obtain the biphasic rate constants for the available aerobic soil degradation results, a dissipation model was structured with two compartments for the parent compound; one adsorbed in such a manner that was not available for biological degradation or abiotic hydrolysis, and the other in which these processes can occur (Fig. 2). The initial thought was to consider these as adsorbed and dissolved compartments, respectively. However, it is known that partitioning of CPY between soil and soil pore water reaches equilibrium within hours (Racke 1993), whereas the biphasic degradation process observed for CPY occurs over a period of several days. The two compartments were identified as Labile CPY and Adsorbed CPY. Reversible movement of parent CPY between these compartments was represented as two simple first-order processes shown by arrows $F_{1}$ and $F_{2}$ in Fig. 2, with rate constants $k_{\text {ads }}$ and $k_{\text {des }}$. This model has advantages over older two-compartment models in that simple first-order equations are used and the rate constants are not concentration-dependent as they are in the Hamaker kinetic equations (Nash 1988). Since the reported concentrations of CPY include both compartments, the model was configured so that measured values are entered as the sum of the amounts in these two compartments at each time point (Fig. 2). The sum of processes that degrade CPY was also described as a first-order kinetic process $\mathrm{F}_{3}$, but was nonreversible. The rate constant for this process was designated $k_{m}$. The resulting set of three first-order equations was integrated numerically using Model-Maker Version 4.0 software from Cherwell Scientific Software Ltd. UK. Metabolism data from 11 soils reported in two studies (Bidlack 1979; de Vette and Schoonmade 2001) were fit to this model. It was assumed that the CPY was entirely in the labile compartment at time-zero, and the rate of degradation was determined by $k_{m}$ and the concentration 
Fig. 3 Correlation of half-life of chlorpyrifos with $\mathrm{pH}$ of soil (data from Bidlack 1979; de Vette and Schoonmade 2001)

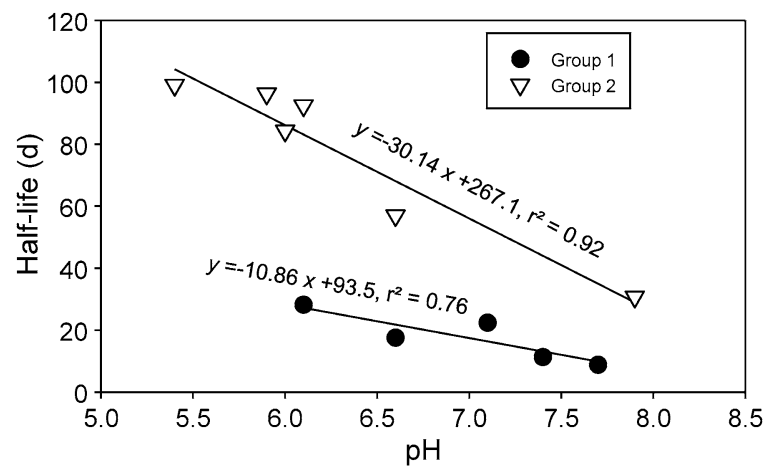

in this compartment. As CPY partitions into the adsorbed compartment, less is available for degradation, and the rate of desorption, described by the rate constant $k_{d e s}$ becomes the rate limiting step. This transition from $k_{m}$ to $k_{d e s}$ creates the biphasic behavior in the model. Further details on the equations used the model set-up and typical results are given in SI Appendix C.

The model results fit the data well (SI Appendix C; SI Table C-2) (Bidlack 1979). The resulting rate constant represents the entire data set for each soil, optimized simultaneously and represents a consistent model across all the soils considered. This provides a better representation of the half-life than the values in the original reports. As noted above, it is expected that the rate constants might be correlated with the physical and chemical properties of the soils such as $\%$ organic matter, etc. No significant correlation could be found among rate constants or half-lives with the $\mathrm{K}_{\mathrm{OC}}$, or water-holding capacity. It has been suggested that there might be a correlation between the rate constant $k_{m}$ for degradation of CPY, and $\mathrm{pH}$ (Bidlack 1979). This is expected, given the dependence of the abiotic hydrolysis on $\mathrm{pH}$, which contributes to this process, but the correlation is not simple. A graph of half-life vs. $\mathrm{pH}$ is shown (Fig. 3). It is possible to consider the data in two groups; one group of soils has half-lives $>30 \mathrm{~d}$, which were $\mathrm{pH}$ dependent; the other group had shorter half-lives with a much weaker correlation to $\mathrm{pH}$.

The correlations for the two groups in the range from $\mathrm{pH} 5$ to 8 are given in (1) and (2).

$$
\begin{aligned}
& \text { Group } 1 \text { half-life }=93.5-10.86 \times p H\left(r^{2}=0.76\right) \\
& \text { Group } 2 \text { half-life }=267-30.14 \times p H\left(r^{2}=0.92\right)
\end{aligned}
$$

The mean half-life in the Group-1 was $17.6 \mathrm{~d}$ with a 90th centile of $25.9 \mathrm{~d}$ and for Group-2 was $77.7 \mathrm{~d}$ with a 90th centile of $97.7 \mathrm{~d}$. The greatest half-life among the U.S. soils in each group was selected as a conservative value to represent the group in simulations with the PRZM/EXAMS model runs used to characterize concentrations in surface waters (Williams et al. 2014). These values were $96 \mathrm{~d}$ from the Stockton soil and $28 \mathrm{~d}$ from the Catlin soil (Table 3). 
Table 3 Half-lives of chlorpyrifos in selected soils recalculated using a two-compartment model

\begin{tabular}{|c|c|c|c|c|}
\hline Soil & $\begin{array}{l}\text { Reported } \\
\mathrm{T}^{1 / 2^{\mathrm{a}}}\end{array}$ & $\begin{array}{l}\text { Calculated } \mathrm{T}^{1} / 2^{1} \text { from } \\
\text { two-compartment model }\end{array}$ & Group & Reference \\
\hline Commerce, MI & 11 & 11 & 2 & Bidlack (1979) \\
\hline Barnes, ND & 22 & 22 & 2 & Bidlack (1979) \\
\hline Miami, IN & 24 & 18 & 2 & Bidlack (1979) \\
\hline Caitlin, IL & 34 & 28 & 2 & Bidlack (1979) \\
\hline Marcham, UK & 43 & 9 & 2 & $\begin{array}{l}\text { de Vette and Schoonmade } \\
\text { (2001) }\end{array}$ \\
\hline Thessaloniki, GR & 46 & 31 & 1 & $\begin{array}{l}\text { de Vette and Schoonmade } \\
\text { (2001) }\end{array}$ \\
\hline Charentilly, FR & 95 & 93 & 1 & $\begin{array}{l}\text { de Vette and Schoonmade } \\
\text { (2001) }\end{array}$ \\
\hline Norfolk, VA & 102 & 57 & 1 & Bidlack (1979) \\
\hline Stockton, CA & 107 & 96 & 1 & Bidlack (1979) \\
\hline Cuckney, UK & 111 & 84 & 1 & $\begin{array}{l}\text { de Vette and Schoonmade } \\
\text { (2001) }\end{array}$ \\
\hline German 2:3 & 141 & 99 & 1 & Bidlack (1979) \\
\hline
\end{tabular}

${ }^{a}$ Rounded to nearest day

${ }^{b}$ For detailed derivation of the data, see SI Appendix B in (Williams et al. 2014)

Adsorption to soil. Based on reported water-soil adsorption coefficients $\left(\mathrm{K}_{\mathrm{OC}}\right)$ of 973 to $31,000 \mathrm{~mL} \mathrm{~g}^{-1}$; mean $8,216 \mathrm{~mL} \mathrm{~g}^{-1}$ (SI Table A-3), CPY has a large potential to adsorb to soil and would not likely be biologically available for uptake by roots of plants. Possible uptake by roots, translocation, and metabolism of CPY in plants also has been investigated (summarized in Racke 1993). In general, negligible amounts enter the plant via the roots. Thus, CPY is not systemic and this pathway of exposure need not be considered in exposure assessments for CPY.

Dissipation from plants. CPY rapidly dissipates from foliar surfaces of plants, primarily due to volatility and secondarily due to photolysis, with most reported dissipation half-lives on the order of several days (Racke 1993). In a field study performed in California that examined mass loss of CPY to air, maximum volatility fluxes occurred in the first $8 \mathrm{~h}$ after application to recently cut alfalfa (Rotondaro and Havens 2012). Total mass loss of CPY, based on the calculated fluxes, ranged between 15.8 and $16.5 \%$ of applied mass, as determined by the Aerodynamic (AD) and Integrated Horizontal Flux (IHF) methodologies, respectively. Data on dissipation of CPY from various crops are provided in SI Table A-4.

Dissipation in aquatic systems. In aquatic systems, abiotic degradation of CPY due to aqueous hydrolysis has been reported to occur with half-lives at $25^{\circ} \mathrm{C}$ of 73,72 , and $16 \mathrm{~d}$ at $\mathrm{pH} 5,7$, and 9, respectively (summarized in Racke 1993). The U.S. EPA (2011a) used an aqueous hydrolysis half-life of $81 \mathrm{~d}$ at $\mathrm{pH} 7$ in modeling to estimate concentrations of CPY in drinking water. Half-lives of 22-51 d have been 
reported from metabolism studies conducted in aerobic aquatic systems (Kennard 1996; Reeves and Mackie 1993). A half-life of $30 \mathrm{~d}$ was reported in an aqueous photolysis study of CPY that was conducted under natural sunlight in sterile $\mathrm{pH} 7$ phosphate buffered solution (Batzer et al. 1990). Data on the dissipation of CPY from aquatic systems are summarized in SI Table A-5.

Field-scale analyses of runoff have demonstrated little potential for CPY to be transported with runoff water (Racke 1993). Chlorpyrifos has been extensively examined in field studies under varying conditions, including greater and lesser antecedent soil moisture, incomplete and full canopy development stages, $2 \mathrm{~h}$ to $7 \mathrm{~d}$ intervals between application and rainfall, maximum soil erosion conditions, different soils properties, and a range of rainfall events up to a 1-in-833 year return frequency (Cryer and Dixon-White 1995; McCall et al. 1984; Poletika and Robb 1994; Racke 1993). Resulting concentrations of CPY in runoff ranged from 0.003 to $4.4 \%$ of the amount applied (McCall et al. 1984; Poletika and Robb 1994). A field runoff study conducted in Mississippi indicated that the majority of chemical mass was transported in the dissolved chemical phase (Poletika and Robb 1994), while a study conducted in Iowa under record high rainfall conditions concluded that the majority of compound was transported attached to eroded sediment (Cryer and Dixon-White 1995).

\section{Toxicity of CPY}

The primary mode of action of organophosphorus insecticides, such as CPY, is well known and has been characterized in mammals (Testai et al. 2010) and in aquatic organisms, particularly fish (Giesy et al. 1999). Chlorpyrifos inhibits the enzyme acetylcholinesterase (AChE) in synaptic junctions of the nervous system. As a result of this inhibition, acetylcholine accumulated in the synapse causes repeated and uncontrolled stimulation of the post-synaptic axon. Disruption of the nervous system that results is the secondary effect that causes the death of the animal. The amino acid sequence of acetylcholinesterase is highly conserved in animals, with the result that CPY is toxic to most groups of animals, although differences in toxicokinetics (adsorption, distribution, metabolism, and excretion-ADME) account for differences in susceptibility among taxa (Timchalk 2010).

\subsection{Mechanism of Action}

The mechanism of action (toxicodynamics) of CPY involves activation by biotic transformation to CPYO, followed by covalent binding to the serine-hydroxyl in the active site of the acetylcholinesterase molecule (Testai et al. 2010) (Fig. 4). While this can occur in the environment (Mackay et al. 2014), in animals this reaction is 

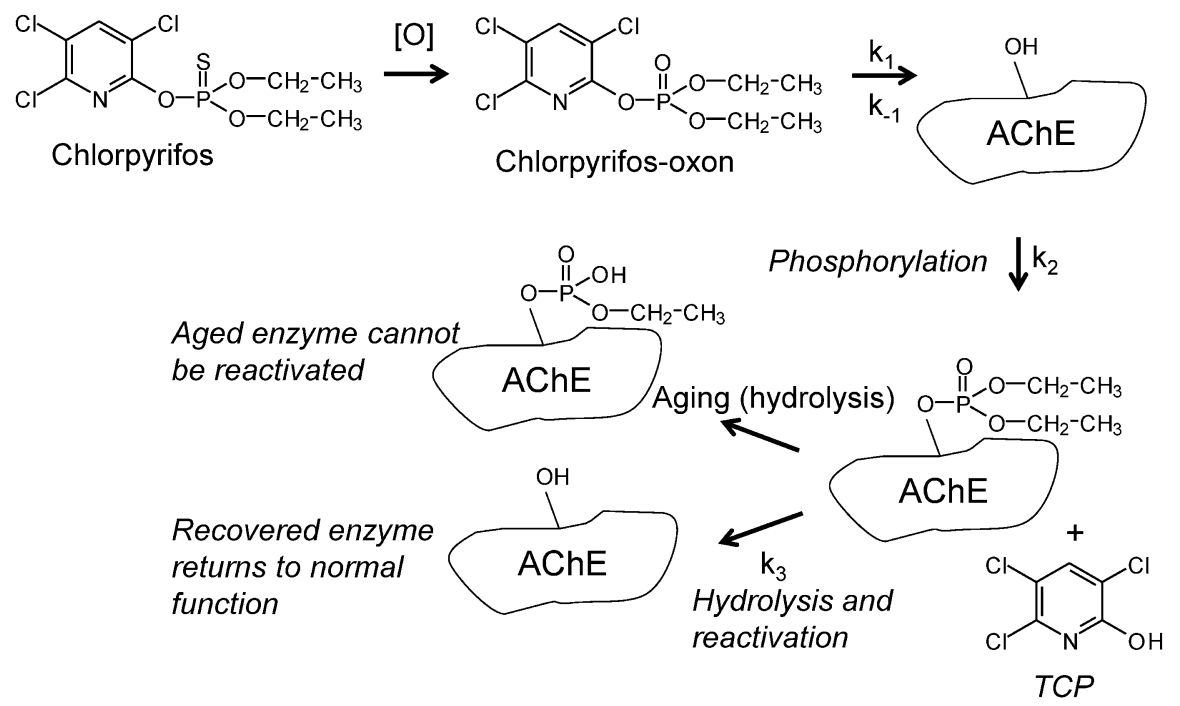

Fig. 4 Diagrammatic representation of the mechanism of action of chlorpyrifos in the nerve synapse

catalyzed by multifunction oxidase enzymes (MFO) and is important in the mode of action of CPY. For example, inhibition of MFOs by the synergist piperonyl butoxide resulted in a decreased toxicity of CPY by up to sixfold in aquatic organisms (El-Merhibi et al. 2004). Chlorpyrifos itself is not a strong inhibitor of AChE, but when transformed to CPYO, the phosphorus atom in the molecule becomes more susceptible to nucleophilic attack by the serine hydroxyl in the active site of AChE. The initial association of CPYO with AChE is reversible $\left(k_{l}, k_{-l}\right.$; Fig. 4) and is modified by the tertiary structure of the enzyme and the inhibitor. During phosphorylation of the serine-OH $\left(k_{2}\right.$; Fig. 4), CPYO is hydrolyzed to release the leaving group TCP (Fig. 4), the reaction is no longer reversible, and AChE is inhibited for as long as it remains phosphorylated. The phosphonic acid moiety is covalently bound to the serine in AChE but the bond can be cleaved by hydrolysis, unless the phosphorylated enzyme ages. If the serine-O-P bond is hydrolyzed by water, AChE is reactivated and normal function returns. If aged via hydrolysis of one of ethylester bonds (Fig. 4), the reactivity of the serine-O-P bond is greatly reduced, AChE cannot be reactivated, and recovery essentially requires the synthesis of new AChE.

The leaving group, TCP, is several orders of magnitude less toxic than CPY or CPYO (Giesy et al. 1999) and is not of toxicological significance (USEPA 2011a). The phosphonic acid released by reactivation of AChE is of low toxicity and is easily excreted from animals (Timchalk 2010). For this reason, the focus of the risk assessments in this series of papers (Cutler et al. 2014; Giddings et al. 2014; Moore et al. 2014) is only on CPY and CPYO. It should be noted that CPYO is the activated form of CPY and its formation in the animal is integral to the mode of action 
of this insecticide, and thus, the toxicity of CPYO is implicitly considered when the toxicity of CPY is studied. As CPYO is also formed in the atmosphere (Mackay et al. 2014), it is considered in the risk assessments.

\subsection{Interactions with Other Pesticides}

Because conversion of CPY to CPYO is essential to the mode of action, compounds that induce multifunction oxidase activity in animals can influence the toxicity of CPY by increasing the rate of formation of CPYO. Atrazine, a herbicide with lesser toxicity than CPY and no activity on AChE, has been reported to synergize (increase or result in supra-additivity) the toxicity of CPY and some other organophosphorus pesticides in aquatic animals such as the midge, Chironomus dilutus (formerly tentans) (Belden and Lydy 2001). The mechanism of this synergism was via induction of multifunction oxidases by atrazine and the resulting increase in the formation of CPYO (Belden and Lydy 2000). Similar synergism has either not been observed or was observed only at small synergistic ratios $(<2)$ in other invertebrates (Trimble and Lydy 2006) and vertebrates (Tyler Mehler et al. 2008; Wacksman et al. 2006). In addition, synergism was only observed at greater concentrations of atrazine and CPY, which rarely co-occur (Rodney et al. 2013). For this reason, synergistic interactions between CPY and other chemicals were not included in the assessment of the risks of CPY to aquatic organisms (Giddings et al. 2014).

Synergism of CPY by the sterol-inhibiting fungicide prochloraz was reported to occur in the red-legged partridge (Johnston et al. 1994), but this was only observed in birds pretreated at a large dose of $180 \mathrm{mg}$ prochloraz $\mathrm{kg}^{-1}$ (bwt), an extremely unlikely exposure in birds. The synergism was attributed to induction of multifunction oxidases and an increase in the formation of CPYO. As for aquatic organisms, interactions of this type were judged to be very unlikely to occur in terrestrial organisms and were not included in the risk assessment.

\section{Use of Chlorpyrifos and Its Formulations}

CPY is a widely used organophosphate pesticide with broad spectrum insecticidal activity. It is used against a broad array of insects and mites, primarily as a contact insecticide, although it does have some efficacy through ingestion. It provides control for many adult and larval forms of insects. Foliar pests for which CPY provides control include: aphids, beetles, caterpillars, leafhoppers, mites, and scale. CPY is also effective against many soil insects, including rootworms, cutworms, wireworms, and other grubs. Although it does not translocate readily, CPY can effectively control boring insects in corn, fruit, and other crops through contact exposure. It can also provide contact control of such insects as case-bearers, orange-worms, and other flies that damage fruits and nuts. The diversity of arthropod pests subject to control with CPY has made it one of most widely used insecticides. 


\subsection{Formulations of Chlorpyrifos}

CPY is currently available as a granular formulation and as several spray formulations. CPY is widely effective against many different insects in various habitats that may attack crop throughout the year. Therefore, it has a wide variety of applications and may be applied to foliage, soil, or dormant trees. Application might occur preplant, at-plant, post-plant or during the dormant season using aerial equipment, chemigation systems, ground-boom sprayers, air-blast sprayers, tractor-drawn spreaders, and hand-held equipment. Dow AgroSciences (and its predecessors) originally developed CPY, but it is now also produced and/or marketed by other registrants of pesticides. The analysis of uses covered in this paper addresses only those CPY products that are registered by Dow AgroSciences, including Special Local Needs labels (SLNs, FIFRA section 24c) for specific States in the U.S. that are based upon these products.

Lorsban $15 G^{\circledR}$ is a granular formulation that contains $15 \%$ (wt/wt) CPY (a.i.) in a solid matrix (Dow AgroSciences 2008). It is used primarily as a soil insecticide, although it can be applied into the whorls of corn to control European corn borer. Applications are in-furrow, banded, and broadcast. One "special local needs" label (FIFRA section 24c State label) was found for use on ginseng in Michigan.

Lorsban $4 E^{\circledR}$ is an emulsifiable concentrate that contains $44.9 \%$ (wt/wt) a.i. (479 $\mathrm{g} \mathrm{L}^{-1}=4$ pounds of per gallon) (Dow AgroSciences 2004). It is used both directly on plants and as a soil treatment. Foliage and woody parts of plants can be treated. Treatments of soil are by broadcast, banded, side-dress, or, for onions and radishes, applied in-furrow. Chemigation is specified for some treatments. There are a few special local needs (24c) labels for the Lorsban 4E, but many old ones have expired and appear to have been replaced by similar labels for Lorsban Advanced ${ }^{\circledR}$.

Lorsban Advanced ${ }^{\circledR}$ is a newer, low odor, water-based version of Lorsban 4E that contains $40.18 \%$ a.i. (wtwt) $\left(450 \mathrm{~g} \mathrm{~L}^{-1}=3.755 \mathrm{lb}\right.$. a.i. per gallon) (Dow AgroSciences 2010). It is used in the same ways as the $4 \mathrm{E}$ formulation but contains smaller quantities of volatile solvents, thus reducing air pollution by VOCs. There are a number of special local needs (24c) labels for Lorsban Advanced that both modify application methods and rates and for several additional crops.

Lorsban $75 W G^{\circledR}$ was registered by EPA late in 2011 (Gowan 2011), but is not yet listed among Dow AgroSciences products. It contains $75 \%$ a.i. (wt/wt) as water dispersible granules for use in many of the same crops as the Lorsban $4 \mathrm{E}$ and Lorsban Advanced formulations. One special local needs (24c) label for peppers in Florida was found that referenced Dow AgroSciences as the registrant, although Gowan Company was the distributor.

Lorsban $50 \mathrm{~W}^{\circledR}$ is a water soluble formulation that contains $50 \%$ a.i. (wt/wt) and is used for treating seeds in commercial establishments (Dow AgroSciences 2007). It is not permitted for such use on farms and other agricultural sites. It does, however, have a supplemental label for use on unspecified trees in the eastern U.S. The treatment is to trunks of trees at a rate of $3 \mathrm{lb}$ a.i./100 gallons of spray, but no amount or limit per acre is specified. A similar use for Lorsban Advanced is only for apple trees in the eastern U.S., but the Lorsban $50 \mathrm{~W}$ label is not limited to any species of tree. 
Rates and methods of application for Lorsban $15 \mathrm{G}$ are summarized in SI Table B-1. Flowable formulations of Lorsban Advanced, Lorsban 4E, and Lorsban 75WG are summarized (SI Tables B-2, B-3, and B-4). The crops, pests, methods, and rates are very similar for these three two flowable formulations. Because Lorsban $50 \mathrm{~W}$ does not have a federal label for application in agricultural settings, it was not included in the tabular information.

\subsection{Environmental Precautions}

All Lorsban products have the standard precautionary labeling involving risks to aquatic organisms, birds, small mammals, and bees. It is not to be applied to water or below the mean high tide level or when bees are visiting the area; dusk to dawn applications are allowed for many uses when bees are active during the day. Labels advise that drift and runoff might be hazardous in water adjacent to treated areas.

Lorsban $15 \mathrm{G}$ has a limitation on aerial application; rates $>1.121 \mathrm{~kg}$ a.i. $\mathrm{ha}^{-1}$ (=1 lb. a.i. $\mathrm{A}^{-1}$ ) are not permitted. Lorsban 4E, Lorsban Advanced, and Lorsban $75 \mathrm{WG}$ have mandatory buffers in their sections on drift-management: Setback buffers from aquatic habitats ("permanent bodies of water such as rivers natural ponds lakes, streams, reservoirs, marshes, estuaries and commercial fish ponds") "must" be utilized: $7.6 \mathrm{~m}(25 \mathrm{ft})$ for ground application and chemigation, $15 \mathrm{~m}$ $(50 \mathrm{ft})$ for orchard air blast, and $45 \mathrm{~m}(150 \mathrm{ft})$ for aerial applications. Aerial applications must follow nozzle and boom width requirements, and applications must neither be made more than $3 \mathrm{~m}(10 \mathrm{ft})$ above the height of the plants (unless required for aircraft safety), nor when wind speed exceeds $16 \mathrm{~km} \mathrm{~h}^{-1}$ (10 $\mathrm{mph}$ ). The above buffers are mandatory. In addition, there are numerous additional recommendations on the label(s) meant to reduce drift. Lorsban Advanced, Lorsban 4E, and Lorsban $75 \mathrm{WG}$ may only be applied by ground spray equipment in Mississippi.

\subsection{Use of Chlorpyrifos in U.S. Field Crops}

Chlorpyrifos is one of the most widely used insecticides in the world. Estimates of annual use in the U.S. since 2008 range from 3.2 to $4.1 \mathrm{M} \mathrm{kg} \mathrm{y}^{-1}$ (7 to $9 \mathrm{M} \mathrm{lb}$ a.i. per annum) (Gomez 2009; Grube et al. 2011). Because of withdrawal of domestic uses, changes in agricultural production, and the introduction of new insecticides, current use is less than $50 \%$ of estimated amounts used in the early 2000s (USEPA 2001). Although there are selected survey data from some states on certain crops, and quantitative usage data from California, there were no other recent applicable data on national usage. Estimates of use vary with the amounts of crops planted or harvested, with climate and pest pressure, and sometimes with recent or local occurrences of new or resistant pests. 


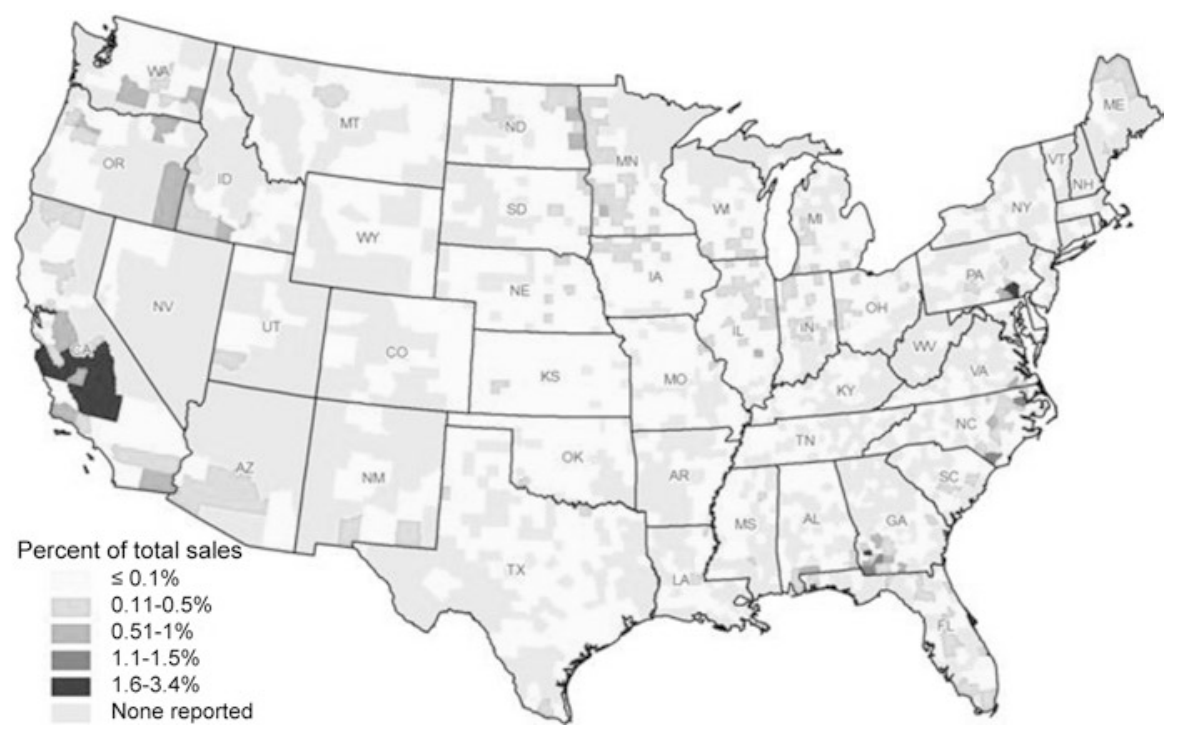

Fig. 5 Geographical distribution of use of granular and liquid formulations of chlorpyrifos in the United States from 2010 to 2011 as \% of total. Derived from unpublished sales data from Dow AgroSciences, Indianapolis, IN

Data on sales of granular and flowable CPY, presented as percent of total use across the U.S. from 2010 to 2011, are provided in Fig. 5 (developed from unpublished sales data from Dow AgroSciences). Regions with the highest percentage of total sales (depicted in blue), include Kern, Tulare, Santa Cruz, Fresno counties in central California; Lancaster County in southeastern Pennsylvania; and Calhoun, Decatur, and Mitchell counties in southeast Georgia.

Since purchases of CPY might not be made close to areas of use, data on sales might not accurately reflect use. Several agencies estimate pesticide use on crops but these estimates are derived from a variety of imprecise sources. Although California's Pesticide Use Reporting (PUR) is based upon the actual amounts reported by pesticide users, all others are derived from sampling and statistical analyses. For specific crops, analysis of CPY use was undertaken by EPA (2008), Gomez (2009), and USDA's National Agricultural Statistics Service (USDA 2012). Usage data for CPY are inclusive of all products from any manufacturer or registrant.

Data on amounts of pesticides used were collected differently by Gomez, USEPA, and USDA. EPA acquired their data from USDA/NASS from 2001 to 2006, proprietary market research data from 2001 to 2006, data from the CropLife Foundation's National Pesticide Use Database, only when other data were not available, and California Pesticide Use Report (PUR) data from 2000 to 2005 when 95\% of the crop was grown in California (USEPA 2008). EPA noted that their estimates included only data from states that were surveyed, rather than for the entire U.S. The reported figures were derived from an algorithm that covers many years but 
gives more weight to recent data so as to give a "current" picture for the period over which the data were developed. Information is consistent across almost all crops and includes the total of active ingredient (a.i.) applied, likely average percent of crop treated and likely maximum percent of crop treated.

Gomez (2009) used proprietary data from 2003 to 2008 and California's PUR data, when that State had more than $40 \%$ of the crop acreage. Gomez does not indicate if the reported usage covers all of the U.S.; it seems likely that the proprietary data would concentrate on states where the most acreage of specific crops was planted. Gomez reported estimated usage for all crops considered both for individual years and averages of 4-5 years. Although Gomez provided valuable data on the percentage of a crop treated, he used different methods of analysis based on proprietary data, which precluded comparisons with EPA and NASS data analyses. Gomez also used data that typically had 3-5 significant figures, while EPA used one significant figure in their estimates, or 2 significant figures for numbers of more than $1,000,000$. Gomez calculated and presented the percent difference between his estimates and those of EPA. Although real differences existed between some numbers, many apparent differences resulted from averaging and different rounding methods.

The NASS performed usage surveys of individual pesticides on certain crops in selected states ("program states") where those crops were most important (http://www.nass.usda.gov/). These surveys are not performed every year. The frequency is dependent upon the crop and typically varies from 3 to $5 \mathrm{y}$. Methods used by NASS are publically available; but, because they are required to protect individual privacy, data are aggregated in ways that sometimes hides useful information. NASS maintains databases of known growers that are stratified in several ways. They typically send out questionnaires to selected samples of growers. Depending upon the nature of the survey, they might follow up by letter, telephone or computer. They analyze these data using standard statistical aggregation. Therefore, the collected data are representative rather than actual, and only apply to the selected states. As a result, the amounts presented as total pesticide applied nationally are likely to be underestimates, the magnitude of which depends upon how much of a particular crop is grown in the states selected for analysis. However, the percentage of crops treated and the amount applied by acre are likely to be comparable in non-selected states. NASS data are reliable for specific states, at least for years that are sampled. Although annual data might be skewed, the comparisons are fairly close among sources when averaged over several years.

A summary of data from the three national sources on the amount of CPY used on various crops is given in Table 4. EPA estimates usage from existing stocks on some crops that are no longer labeled, but these are not included in Table 4. NASS usage estimates are only given for the latest year, although the amount of CPY used will vary considerably from year to year, depending upon pest pressure. 
Table 4 Summary of amount of chlorpyrifos used and percentage of crop treated for selected crop sites

\begin{tabular}{|c|c|c|c|c|c|}
\hline Crop & $\begin{array}{l}\text { Ave. lbs. }{ }^{\mathrm{a}} \text { a.i. } \\
\text { applied } \\
\text { (Gomez 2009) } \\
\text { from Doane }\end{array}$ & $\begin{array}{l}\text { Ave. lbs. a.i. } \\
\text { applied } \\
\text { (USEPA 2008) }\end{array}$ & $\begin{array}{l}\text { Ave. } \% \\
\text { crop treated } \\
\text { (USEPA } \\
\text { 2008) }\end{array}$ & $\begin{array}{l}\text { Ave. lbs. a.i. } \\
\text { applied (NASS } \\
\text { program states } \\
\text {-latest year) } \\
\text { (USDA 2012) }^{\text {b }}\end{array}$ & $\begin{array}{l}\text { Ave. } \% \\
\text { crop treated } \\
\text { (NASS) } \\
\text { (USDA } \\
2012 \text { ) }\end{array}$ \\
\hline Alfalfa & 374,750 & 400,000 & 5 & & \\
\hline Almonds & 341,991 & 500,000 & 30 & & \\
\hline Asparagus & 22,104 & 20,000 & 25 & 211,100 & 44 \\
\hline Apples & 414,600 & 400,000 & 55 & & \\
\hline Beans, green & 4,119 & 3,000 & $<1$ & & \\
\hline Beans \& peas, dry & & 4,000 & $<1$ & & \\
\hline Broccoli & 60,385 & 90,000 & 45 & & \\
\hline Brussels Sprouts & & 6,000 & $\mathrm{n} / \mathrm{c}$ & & \\
\hline Cabbage & 7,055 & 10,000 & 10 & & \\
\hline $\begin{array}{l}\text { Carrots } \\
\quad(\text { SLN-WA })\end{array}$ & & 1,000 & $<2.5$ & & \\
\hline Cauliflower & 15,239 & 20,000 & 40 & & \\
\hline Cherries, all & 80,140 & 60,000 & 30 & 36,300 & $16-23$ \\
\hline Christmas trees & & & & 26,600 & $16-20$ \\
\hline Corn & $2,617,432$ & $3,000,000$ & 5 & 478,000 & 1 \\
\hline Cotton & 285,350 & 200,000 & $<1$ & & \\
\hline Cranberries & & 50,000 & 70 & & \\
\hline Grapefruit & 54,855 & 60,000 & 15 & 42,500 & 19 \\
\hline Grapes, wine & 68,603 & & & 64,500 & 4 \\
\hline Grapes, table & 60,428 & & & 40,000 & 12 \\
\hline Grapes, all & & 100,000 & 5 & & \\
\hline Hazelnuts & 7,286 & 7,000 & 15 & & \\
\hline Lemons & 47,033 & 90,000 & 35 & 22,800 & 12 \\
\hline Mint & & 50,000 & 25 & & \\
\hline Nectarines & & 20,000 & 20 & 3,400 & 5 \\
\hline Onions, dry & 68,805 & 60,000 & 35 & 51,100 & $30-32$ \\
\hline Oranges & 241,735 & 300,000 & 10 & 194,800 & 12 \\
\hline Peaches & 69,853 & 70,000 & 30 & 8,900 & 7 \\
\hline Peanuts & 119,213 & 200,000 & 5 & & \\
\hline Pears & 29,564 & 30,000 & 20 & 11,300 & 10 \\
\hline Peas, green & & $<500$ & $<1$ & & \\
\hline Pecans & 296,596 & 300,000 & 35 & & \\
\hline $\begin{array}{l}\text { Peppers } \\
\quad \text { (SLN-FL) }\end{array}$ & & 2,000 & $<1$ & & \\
\hline Plums \& Prunes & 18,674 & 40,000 & & & \\
\hline Plums & & & 15 & 2,400 & 7 \\
\hline Prunes & & & 10 & & \\
\hline Sod/turf & & 2,000 & $\mathrm{n} / \mathrm{c}$ & & \\
\hline Sorghum & & 30,000 & $<1$ & & \\
\hline
\end{tabular}


Table 4 (continued)

\begin{tabular}{|c|c|c|c|c|c|}
\hline Crop & $\begin{array}{l}\text { Ave. lbs. }{ }^{\mathrm{a}} \text { a.i. } \\
\text { applied } \\
\text { (Gomez 2009) } \\
\text { from Doane }\end{array}$ & $\begin{array}{l}\text { Ave. lbs. a.i. } \\
\text { applied } \\
\text { (USEPA 2008) }\end{array}$ & $\begin{array}{l}\text { Ave. } \% \\
\text { crop treated } \\
\text { (USEPA } \\
\text { 2008) }\end{array}$ & $\begin{array}{l}\text { Ave. lbs. a.i. } \\
\text { applied (NASS } \\
\text { program states } \\
\text {-latest year) } \\
\text { (USDA 2012) }^{\mathrm{b}}\end{array}$ & $\begin{array}{l}\text { Ave. \% } \\
\text { crop treated } \\
\text { (NASS) } \\
\text { (USDA } \\
\text { 2012) } \\
\end{array}$ \\
\hline Soybeans & $1,017,953$ & 700,000 & $<1$ & & \\
\hline Strawberries & 10,043 & 9,000 & 15 & 7,700 & 15 \\
\hline Sugar Beets & 138,020 & 100,000 & 10 & & \\
\hline Sunflowers & 34,857 & 20,000 & $<1$ & & \\
\hline Sweet Corn & 120,881 & 100,000 & 10 & 36,500 & $13-23$ \\
\hline Sweet potatoes & & 100,000 & 65 & & \\
\hline $\begin{array}{l}\text { Tangelos \& } \\
\text { tangerines }\end{array}$ & & 8,000 & 10 & 8,300 & $7-19$ \\
\hline Tobacco & 98,468 & 100,000 & 15 & & \\
\hline Walnuts & 195,505 & 400,000 & 45 & & \\
\hline Wheat & 288,751 & 300,000 & $<1$ & 577,000 & $2-3$ \\
\hline Total & & & & & \\
\hline
\end{tabular}

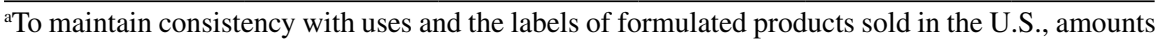
of CPY applied are given in imperial units (pounds (lbs.))

${ }^{\mathrm{b}}$ Generally this is 2011 for fruits and 2010 for other crop

${ }^{\mathrm{c}}$ Special Label Needs

\subsection{Timing of the Use of Chlorpyrifos}

CPY is normally applied to coincide with infestations of pests, which vary from one location to another. Timing of application of CPY in relation to local climatic conditions, rainfall, and patterns of weather might have significant effects on the degradation, potential for movement, and exposures of non-target organisms. To properly characterize timing of the use of CPY, we relied on the USDA publication "Usual Planting and Harvesting Dates for U.S. Field Crops" (USDA 2010) and other sources (i.e., mainly state extension services and the internet). These data are summarized in Table 5 for crops that are in the field year round, and in Table 6 for crops that are seasonal.

From these data, it is apparent that there is no strong seasonal use of CPY, although there is a somewhat greater usage in winter months for tree crops in California and greater use in summer for certain field crops (e.g., corn). These use patterns and how they affect scenarios for exposures are discussed in more detail in the companion papers of this volume (Moore et al. 2014; Williams et al. 2014).

\section{Summary}

Physical properties and use data provide the basis for estimating environmental exposures to chlorpyrifos (CPY) and for assessing its risks. The vapor pressure of CPY is low, solubility in water is $<1 \mathrm{mg} \mathrm{L}^{-1}$, and its $\log \mathrm{K}_{\mathrm{OW}}$ is 5 . Chlorpyrifos has 
Table 5 Timing of chlorpyrifos use for crops in the U.S. that are in the field all year (Jan to Dec)

\begin{tabular}{|c|c|c|c|c|c|c|c|c|c|c|c|c|}
\hline \multirow[b]{2}{*}{ Crop and location } & \multicolumn{12}{|c|}{ Months of the year in which CPY is applied } \\
\hline & $\mathbf{J}$ & $\mathbf{F}$ & M & A & M & $\mathbf{J}$ & $\mathbf{J}$ & A & $\mathbf{S}$ & 0 & $\mathbf{N}$ & D \\
\hline \multicolumn{13}{|l|}{ Alfalfa, warmer states (CA, $A Z$, etc.) } \\
\hline \multicolumn{13}{|l|}{ Cooler states } \\
\hline \multicolumn{13}{|l|}{ Southern MO } \\
\hline \multicolumn{13}{|l|}{ Northern MO } \\
\hline \multicolumn{13}{|l|}{ Apple tree trunks } \\
\hline \multicolumn{13}{|l|}{ Asparagus CA only Southern desert } \\
\hline \multicolumn{13}{|l|}{ Delta } \\
\hline \multicolumn{13}{|l|}{ Central coast } \\
\hline \multicolumn{13}{|l|}{ Other U.S. } \\
\hline \multicolumn{13}{|l|}{ Brassica (cole) leafy vegetables } \\
\hline \multicolumn{13}{|l|}{ Brussels sprouts } \\
\hline \multicolumn{13}{|l|}{ Carrots for seed OR \& WA } \\
\hline \multicolumn{13}{|l|}{ Christmas tree } \\
\hline \multicolumn{13}{|l|}{ Citrus orchard floors } \\
\hline \multicolumn{13}{|l|}{ Citrus fruits } \\
\hline \multicolumn{13}{|l|}{ Cranberry } \\
\hline \multicolumn{13}{|l|}{ Fig (CA only) } \\
\hline \multicolumn{13}{|l|}{ Ginseng $\left(\mathrm{MI}, \mathrm{WI}-\mathrm{SLN}^{\mathrm{a}}\right)$} \\
\hline \multicolumn{13}{|l|}{ Grape ( $E$ of Continental Divide only) } \\
\hline Grapes (CA-SLN) & & & & & & & & & & & & \\
\hline Grass and clover for seed (NV, ID, & & & & & & & & & & & & \\
\hline Legume vegetables (except soybe & & & & & & & & & & & & \\
\hline Onion (dry bulb) & & & & & & & & & & & & \\
\hline Pears (CA, OR, \& WA only) & & & & & & & & & & & & \\
\hline Peppers (FL only - special local ne & & & & & & & & & & & & \\
\hline Pineapple ( $\mathrm{HI}$ only - special local $r$ & & & & & & & & & & & & \\
\hline Pulpwood (cottonwood \& poplar, & & & & & & & & & & & & \\
\hline Strawberries & & & & & & & & & & & & \\
\hline Tree fruits and nuts - all applicati & & & & & & & & & & & & \\
\hline Apples (all U.S.) & & & & & & & & & & & & \\
\hline Apples (eastern U.S.) & & & & & & & & & & & & \\
\hline Cherry & & & & & & & & & & & & \\
\hline Filbert & & & & & & & & & & & & \\
\hline Nectarine & & & & & & & & & & & & \\
\hline Peach & & & & & & & & & & & & \\
\hline Pear & & & & & & & & & & & & \\
\hline Pecan & & & & & & & & & & & & \\
\hline Plum & & & & & & & & & & & & \\
\hline Prune & & & & & & & & & & & & \\
\hline Walnut & & & & & & & & & & & & \\
\hline Turfgrass & & & & & & & & & & & & \\
\hline Wheat (W of the Mississippi River) & & & & & & & & & & & & \\
\hline
\end{tabular}

(continued) 
Table 5 (continued)

${ }^{a}$ Special Label Needs

Data from:

USDA (2010)

Missouri Extension Service: http://extension.missouri.edu/p/G4550

http://ohioline.osu.edu/b826/b826_14.html

http://www.pickyourown.org/FLcitrus.htm; http://www.pickyourown.org/CAharvest calendar. htm

Seasonal Patterns of Citrus Bloom, by William A. Simanton, Florida Agricultural Experiment Station Journal Series No. 3426. Florida State Horticultural Society, 1969, pp 96-98

http://en.wikipedia.org/wiki/Cranberry; http://www.wenatcheeworld.com/news/2011/oct/07/

cranberry-harvest-under-way-on-wa-coastal-bogs/; http://www.capecodtravel.com/attractions/ nature/ cranberries0900.shtml

Morton, J. 1987. Fig. p. 47-50. In: Fruits of warm climates. Julia F. Morton, Miami, FL. @ http:// www.hort.purdue.edu/newcrop/morton/fig.html; also http://www.latimes.com/features/ la-fo-market 16-2008jul16,0,4856462.story

http://en.wikipedia.org/wiki/Cranberry; http://www.wenatcheeworld.com/news/2011/oct/07/ cranberry-harvest-under-way-on-wa-coastal-bogs/; http://www.capecodtravel.com/attractions/nature/ cranberries0900.shtmll

Monitoring and Control Tactics for Grape Root Borer Vitacea polistiformis Harris (Lepidoptera: Sesiidae) in Florida Vineyards. By Scott Weihman. Master's Degree Thesis, University of Florida, 2005 @ http://etd.fcla.edu/UF/UFE0009182/weihman_s.pdf

The Grape Root Borer in Tennessee, by P. Parkman, D. Lockwood, and F. Hale, University of Tennessee Extension Service publication W171, 2007. @ https://utextension.tennessee.edu/ publications/documents/W171.pdf www.nysipm.cornell.edu/factsheets/grapes/pests/gcb.pdf http://www.calagquest.com/BloomTime.php http://sacramentogardening.com/edible_gardening.html http://wiki.answers.com/Q/What_time_of_year_do_you_grow_peas

Pest Management Strategic Plan for Dry Bulb Storage Onions in Colorado, Idaho, Oregon, Utah, and Washington. Summary of a workshop held on February 26-27, 2004. Boise, ID. @ http://www. ipmcenters.org/pmsp/pdf/WesternONION.pdf

http://aggie-horticulture.tamu.edu/archives/parsons/publications/onions/oniongro.html

http://edis.ifas.ufl.edu/mv112

http://www.ctahr.hawaii.edu/oc/freepubs/pdf/f_n-7.pdf

http://www.strawberry-recipes.com/plant-strawberries.html

http://strawberryplants.org/2010/05/strawberry-varieties/

short to moderate persistence in the environment as a result of several dissipation pathways that may proceed concurrently. Primary mechanisms of dissipation include volatilization, photolysis, abiotic hydrolysis, and microbial degradation. Volatilization dominates dissipation from foliage in the initial $12 \mathrm{~h}$ after application, but decreases as CPY adsorbs to foliage or soil. In the days after application, CPY adsorbs more strongly to soil, and penetrates more deeply into the soil matrix, becoming less available for volatilization. After the first $12 \mathrm{~h}$, other processes of degradation, such as chemical hydrolysis and catabolism by microbiota become important. The half-life of CPY in soils tested in the laboratory ranged from 2 to $1,575 \mathrm{~d}(\mathrm{~N}=126)$ and is dependent on properties of the soil and rate of application. At application rates used historically for control of termites, the degradation rate is much slower than for agricultural uses. In agricultural soils under field conditions, half-lives are shorter ( 2 to $120 \mathrm{~d}, \mathrm{~N}=58$ ). The mean water-soil adsorption coefficient $\left(\mathrm{K}_{\mathrm{OC}}\right)$ of $\mathrm{CPY}$ is $8,216 \mathrm{~mL} \mathrm{~g}^{-1}$; negligible amounts enter plants via the roots, and it is not translocated in plants. 
Table 6 Timing of chlorpyrifos use for crops in the U.S. that are in the field part of the year

\begin{tabular}{|c|c|c|c|c|c|c|c|c|c|c|c|c|}
\hline \multirow[b]{2}{*}{ Crop in field, location, and use of CPY } & \multicolumn{12}{|c|}{ Months of the year in which CPY is applied } \\
\hline & $\mathbf{J}$ & $\mathbf{F}$ & M & $\mathbf{A}$ & M & $\mathbf{J}$ & $J$ & $\mathbf{A}$ & $\mathbf{S}$ & 0 & $\mathbf{N}$ & D \\
\hline \multicolumn{13}{|l|}{ Corn, Southern states in field } \\
\hline \multicolumn{13}{|l|}{ Use of CPY } \\
\hline \multicolumn{13}{|l|}{ Northern states in field } \\
\hline \multicolumn{13}{|l|}{ Use of CPY } \\
\hline \multicolumn{13}{|l|}{ Cotton, Southern areas in field } \\
\hline \multicolumn{13}{|l|}{ Use of CPY } \\
\hline \multicolumn{13}{|l|}{ Northern areas $+\mathrm{CA}$ in field } \\
\hline \multicolumn{13}{|l|}{ Use of CPY } \\
\hline \multicolumn{13}{|l|}{ Peanuts, in field } \\
\hline \multicolumn{13}{|l|}{ Use of CPY } \\
\hline \multicolumn{13}{|l|}{ Peppermint and Spearmint, in field } \\
\hline \multicolumn{13}{|l|}{ Use of CPY } \\
\hline \multicolumn{13}{|l|}{ Sorghum, in field } \\
\hline \multicolumn{13}{|l|}{ Use of CPY } \\
\hline \multicolumn{13}{|l|}{ Soybeans, in field } \\
\hline \multicolumn{13}{|l|}{ Use of CPY } \\
\hline \multicolumn{13}{|l|}{ Sugarbeets, in field Imperial Valley, CA } \\
\hline \multicolumn{13}{|l|}{ Use of CPY } \\
\hline \multicolumn{13}{|l|}{ Other locations in field } \\
\hline \multicolumn{13}{|l|}{ Use of CPY } \\
\hline \multicolumn{13}{|l|}{ Sunflowers, in field CA } \\
\hline \multicolumn{13}{|l|}{ Use of CPY } \\
\hline \multicolumn{13}{|l|}{ TX \& OK in field } \\
\hline \multicolumn{13}{|l|}{ Use of CPY } \\
\hline Other states in field & & & & & & & & & & & & \\
\hline Use of CPY & & & & & & & & & & & & \\
\hline Sweet potato, in field & & & & & & & & & & & & \\
\hline Use of CPY & & & & & & & & & & & & \\
\hline Tobacco, in field New England \& PA & & & & & & & & & & & & \\
\hline Use of CPY & & & & & & & & & & & & \\
\hline Southern states in field & & & & & & & & & & & & \\
\hline Use of CPY & & & & & & & & & & & & \\
\hline
\end{tabular}

Data from: (Chen et al. 2011; USDA 2010; Zheljazkov et al. 2010)

Half-lives for hydrolysis in water are inversely dependent on $\mathrm{pH}$, and range from 16 to $73 \mathrm{~d}$. CPY is an inhibitor of acetylcholinesterase and is potentially toxic to most animals. Differences in susceptibility result from differences in rates of adsorption, distribution, metabolism, and excretion among species. CPY is an important tool in management of a large number of pests (mainly insects and mites) and is used on a wide range of crops in the U.S. Estimates of annual use in the U.S. from 2008 to 2012 range from 3.2 to $4.1 \mathrm{M} \mathrm{kg} \mathrm{y}^{-1}$, which is about $50 \%$ less than the amount used prior to 2000. Applications to corn and soybeans accounts for 46-50\% of CYP's annual use in the U.S. 
Acknowledgements The authors thank Kendall Price, Waterborne, and Larry Turner, Compliance Services International, for compiling information on the properties and use of chlorpyrifos. We thank the anonymous reviewers of this paper for their suggestions and constructive criticism. Prof. Giesy was supported by the Canada Research Chair program, a Visiting Distinguished Professorship in the Department of Biology and Chemistry and State Key Laboratory in Marine Pollution, City University of Hong Kong, the 2012 "High Level Foreign Experts" (\#GDW20123200120) program, funded by the State Administration of Foreign Experts Affairs, the P.R. China to Nanjing University and the Einstein Professor Program of the Chinese Academy of Sciences. Funding for this study was provided by Dow AgroSciences.

Open Access This chapter is distributed under the terms of the Creative Commons Attribution Noncommercial License, which permits any noncommercial use, distribution, and reproduction in any medium, provided the original author(s) and source are credited.

\section{References}

Batzer FR, Fontaine DD, White FH (1990) aqueous photolysis of chlorpyrifos. DowElanco, Midland, MI, Unpublished Report

Belden JB, Lydy MJ (2000) Impact of atrazine on organophosphate insecticide toxicity. Environ Toxicol Chem 19:2266-2274

Belden JB, Lydy MJ (2001) Effects of atrazine on acetylcholinesterase activity in midges (Chironomus tentans) exposed to organophosphorus insecticides. Chemosphere 44:1685-1689

Bidlack HD (1979) Degradation of chlorpyrifos in soil under aerobic, aerobic/anaerobic and anaerobic conditions. Dow Chemical, Midland, MI, Unpublished Report

Chapman RA, Harris CR (1980) Persistence of chlorpyrifos in a mineral and an organic soil. J Environ Sci Health B 15:39-46

Chen MZ, Trinnaman L, Bardsley K, St Hilaire CJ, Da Costa NC (2011) Volatile compounds and sensory analysis of both harvests of double-cut Yakima peppermint (Mentha piperita L.). J Food Sci 76:C1032-C1038

Cryer S, Dixon-White H (1995) A field runoff study of chlorpyrifos in southeast iowa during the severe flooding of 1993. Indianapolis, IN, DowElanco, Unpublished Report

Cutler GC, Purdy J, Giesy JP, Solomon KR (2014) Risk to pollinators from the use of chlorpyrifos in the United States. Rev Environ Contam Toxicol 231:219-265

de Vette HQM, Schoonmade JA (2001) A study on the route and rate of aerobic degradation of ${ }^{14} \mathrm{C}$-chlorpyrifos in four European soils. Dow AgroSciences, Indianapolis, IN, Unpublished Report

Dow AgroSciences D (2004) Lorsban 4E insecticide label. Dow AgroSciences LLC, Indianapolis, IN

Dow AgroSciences (2007) Lorsban 50W wettable powder insecticide label. Dow Agrosciences Canada, Calgary, AB, Canada. http://msdssearch.dow.com/PublishedLiteratureDAS/dh_00e9/ 0901b803800e9ceb.pdf?filepath=ca/pdfs/noreg/010-20642.pdf \&fromPage=GetDoc

Dow AgroSciences (2008) Lorsban 15G granular insecticide specimen label. Dow AgroSciences LLC, Indianapolis, IN

Dow AgroSciences (2010) Lorsban advanced insecticide label. Dow AgroSciences LLC, Indianapolis, IN

El-Merhibi A, Kumar A, Smeaton T (2004) Role of piperonyl butoxide in the toxicity of chlorpyrifos to Ceriodaphnia dubia and Xenopus laevis. Ecotoxicol Environ Safety 57:202-212

Gebremariam SY, Beutel MW, Yonge DR, Flury M, Harsh JB (2012) Adsorption and desorption of chlorpyrifos to soils and sediments. Rev Environ Contam Toxicol 215:123-175 
Giddings JM, Williams WM, Solomon KR, Giesy JP (2014) Risks to aquatic organisms from the use of chlorpyrifos in the United States. Rev Environ Contam Toxicol 231:119-162

Giesy JP, Solomon KR, Coates JR, Dixon KR, Giddings JM, Kenaga EE (1999) Chlorpyrifos: ecological risk assessment in North American aquatic environments. Rev Environ Contam Toxicol 160:1-129

Gomez LE (2009) Use and benefits of chlorpyrifos in U.S. agriculture. Dow AgroSciences, Indianapolis, IN, Unpublished Report

Gowan (2011) Lorsban 75WG Label. Gowan Company, Yuma, AZ. http://www. keystonepestsolutions.com/labels/Lorsban_75WG.pdf

Grube A, Donaldson D, Kiely T, Wu L (2011) Pesticides industry sales and usage: 2006 and 2007 market estimates. United States Environmental Protection Agency, Office of Pesticide Programs, Biological and Economic Analysis Division, Washington, DC, EPA 733-R-11-001

Johnston G, Walker CH, Dawson A (1994) Interactive effects between EBI fungicides (prochloraz, propiconazole and penconazole) and OP insecticides (dimethoate, chlorpyrifos, diazinon and malathion) in the hybrid red-legged partridge. Environ Toxicol Chem 13:615-620

Kennard LM (1996) Aerobic aquatic degradation of chlorpyrifos in a flow-through system. DowElanco, Indianapolis, IN, Unpublished Report

Mackay D, Giesy JP, Solomon KR (2014) Fate in the environment and long-range atmospheric transport of the organophosphorus insecticide, chlorpyrifos and its oxon. Rev Environ Contam Toxicol 231:35-76

McCall PJ, Oliver GR, McKellar RL (1984) Modeling the runoff potential and behavior of chlorpyrifos in a terrestrial-aquatic watershed. Midland, MI, Dow Chemical, Unpublished Report

Moore DRJ, Teed RS, Greer C, Solomon KR, Giesy JP (2014) Refined avian risk assessment for chlorpyrifos in the United States. Rev Environ Contam Toxicol 231:163-217

Nash RG (1988) Dissipation from soil. In: Grover R (ed) Environmental chemistry of the herbicides, vol 1. CRC Press, Boca Raton, FL, pp 131-170

Poletika NN, Robb CK (1994) A field runoff study of chlorpyrifos in Mississippi delta cotton. Indianapolis, IN, DowElanco, Unpublished Report

Racke KD, Coats JR, Titus KR (1988) Degradation of chlorpyrifos and its hydrolysis product, 3,5,6-trichloro-2-pyridinol in soil. J Environ Sci Health B 23:527-539

Racke KD (1993) Environmental fate of chlorpyrifos. Rev Environ Contam Toxicol 131:1-151

Reeves GL, Mackie JA (1993) The aerobic degradation of ${ }^{14} \mathrm{C}$-chlorpyrifos in natural waters and associated sediments. Dow Agrosciences, Indianapolis, IN, Unpublished Report

Rodney SI, Teed RS, Moore DRJ (2013) Estimating the toxicity of pesticide mixtures to aquatic organisms: A review. Human Ecol Risk Assess 19:1557-1575

Rotondaro A, Havens PL (2012) Direct flux measurement of chlorpyrifos and chlorpyrifos-oxon emissions following applications of Lorsban Advanced insecticide to alfalfa. Dow AgroScience, Indianapolis, IN, Unpublished Report

Rouchaud J, Metsue M, Gustin F, van de Steene F, Pelerents C, Benoit F, Ceustermans N, Gillet J, Vanparys L (1989) Soil and plant biodegradation of chlorpyrifos in fields of cauliflower and Brussels sprouts crops. Toxicol Environ Chem 23:215-226

Solomon KR, Giesy JP, Kendall RJ, Best LB, Coats JR, Dixon KR, Hooper MJ, Kenaga EE, McMurry ST (2001) Chlorpyrifos: ecotoxicological risk assessment for birds and mammals in corn agroecosystems. Human Ecol Risk Assess 7:497-632

Testai E, Buratti FM, Consiglio ED (2010) Chlorpyrifos. In: Krieger RI, Doull J, van Hemmen JJ, Hodgson E, Maibach HI, Ritter L, Ross J, Slikker W (eds) Handbook of pesticide toxicology, vol 2. Elsevier, Burlington, MA, pp 1505-1526

Timchalk C (2010) Organophosphorus insecticide pharmacokinetics. In: Krieger RI, Doull J, van Hemmen JJ, Hodgson E, Maibach HI, Ritter L, Ross J, Slikker W (eds) Handbook of pesticide toxicology, vol 2. Elsevier, Burlington, MA, pp 1409-1433

Trimble AJ, Lydy MJ (2006) Effects of triazine herbicides on organophosphate insecticide toxicity in Hyalella azteca. Arch Environ Contam Toxicol 51:29-34

Tyler Mehler W, Schuler LJ, Lydy MJ (2008) Examining the joint toxicity of chlorpyrifos and atrazine in the aquatic species: Lepomis macrochirus, Pimephales promelas and Chironomus tentans. Environ Pollut 152:217-224 
USDA (2010) Usual Planting and Harvesting Dates for U.S. Field Crops. United States Department of Agriculture, National Agricultural Statistics Service pp 51

USDA (2012) National Agricultural Statistics Service. United States Department of Agriculture. Accessed 2012 April, August and September. http://www.nass.usda.gov/Surveys/Guide_to_ NASS_Surveys/Chemical_Use/index.asp

USEPA (2001) Chlorpyrifos Interim Reregistration Eligibility Decision Document (IRED). United States Environmental Protection Agency, Washington, DC

USEPA (2008) CHLORPYRIFOS 059101 Screening Level Usage Analysis (SLUA). United States Environmental Protection Agency, Docket ID \#EPA-HQ-OPP-2008-0850-0005 http:// www.regulations.gov/\#!documentDetail; D=EPA-HQ-OPP-2008-0850-0005

USEPA (2011a) Interim guidance on honey bee data requirements. United States Environtmental Protection Agency, Environmental Fate and Effects Division, Office of Pesticide Programs, Washington, DC. http://www.epa.gov/oppefed1/ecorisk_ders/honeybee_data_interim_guidance.htm

USEPA (2011b) Revised chlorpyrifos preliminary registration review drinking water assessment. United States Environmental Protection Agency, Office of Chemical Safety and Pollution Prevention, Washington, DC, PC Code 059101 http://www.epa.gov/oppsrrd1/registration review/chlorpyrifos/EPA-HQ-OPP-2008-0850-DRAFT-0025\%5B1\%5D.pdf

Wacksman MN, Maul JD, Lydy MJ (2006) Impact of atrazine on chlorpyrifos toxicity in four aquatic vertebrates. Arch Environ Contam Toxicol 51:681-689

Williams WM, Giddings JM, Purdy J, Solomon KR, Giesy JP (2014) Exposures of aquatic organisms to the organophosphorus insecticide, chlorpyrifos resulting from use in the United States. Rev Environ Contam Toxicol 231:77-118

Yon D (2011) Modelling the kinetics of the degradation of chlorpyrifos and its metabolites in field soil—rate constant normalisation method. Dow AgroSciences European Development Centre, Abingdon, Unpublished Report

Zheljazkov VD, Cantrell CL, Astatkie T, Hristov A (2010) Yield, content, and composition of peppermint and spearmints as a function of harvesting time and drying. J Agric Food Chem 58:11400-11407 